\title{
Cervical Sagittal Balance as a Predictor for the Outcome of Multimodal Treatment Program for Non Specific Neck Pain
}

\author{
MOHAMED A. NEAMTALLAH, M.Sc.; NEVEEN ABDALATEF, Ph.D.; REHAM H. DIAB, Ph.D. and \\ ALIAA A. DIAB, Ph.D.
}

The Department of Basic Sciences, Faculty of Physical Therapy, Cairo University

\begin{abstract}
Background: Sagittal balance represents the position of the occiput to the thoracic inlet. Sagittal balance keep normal lordotic curve in cervical region so any disturbance in cervical balance lead to pain and disability. Also it an important concept in spinal reconstruction and cervical sagittal imbalance has been linked to poor health-related quality of life scores due to disabling symptoms of neck pain and neurological deficit.

Aim of Study: The purpose of this study was to investigate the influence of cervical balance as predictor for the outcome measures of multimodal treatment program in patient with non specific neck pain.

Patients and Methods: Forty patients with non specific neck pain participated in this study. Patients were subdivided into two groups, twenty in each group. The first group was the group A with cervical sagittal imbalance, and the second group was the group B with cervical sagittal balance. Both groups received multimodal treatment (cervicothoracic stabilization training designed to restore cervical muscle endurance and coordination, relaxation training to reduce unnecessary muscle tension, behavioral support to reduce anxiety and fear of pain, eye fixation exercises to prevent dizziness and seated wobble-board training to improve postural control). We measured pain by Visual Analogue Scale (VAS), neck function by Neck Disability Index (NDI) and cervical Range of Motion (ROM) by cervical goniometer.

Results: Within-group analysis there was a significant difference of, NDI and ROM (flexion, extension, RT rotation and $\mathrm{LT}$ rotation) pre-treatment at groups $\mathrm{A}, \mathrm{B}(p=0.0001)$ There was no significant difference of VAS, LT bending and RT bending pre-treatment ( $p$-value $>0.05$ ). Between group analyses there was significant difference of NDI and ROM (flexion, extension, RT bending, LT bending, RT rotation and LT rotation) in two groups post-treatment as $p$-value $<0.05$ except VAS.
\end{abstract}

SVA (Sagittal Vertical Axis) contribute to interpretation of changes in ROM NDI except VAS.

Conclusion: Cervical sagittal balance is effective in predicting multimodal treatment outcome measures (ROM

Correspondence to: Dr. Mohamed A. Neamtallah, The Department of Basic Sciences, Faculty of Physical Therapy, Cairo University and neck function) in Nonspecific Neck Pain (NSNP). Patients with cervical sagittal balance have better outcome measures (improving ROM and improving neck function) than patients with cervical sagittal imbalance in case of non specific neck pain.

Key Words: Cervical - Sagittal balance - MultimodalTreatment.

\section{Introduction}

NECK pain is one of the most common and painful musculoskeletal conditions. Point prevalence ranges from $6 \%$ to $22 \%$ and up to $38 \%$ of the elderly population, while lifetime prevalence ranges from $14,2 \%$ to $71 \%$ [1]. For the majority of the neck disorders there is an absence of an identifiable underlying disease or abnormal anatomical structure. As aconsequence they are classified as 'nonspecific' [2].

This creates a lack of a "gold standard" assessment for NS-NP. From this perspective NS-NP is mainly 'diagnosed' on the basis of clinical grounds, provided there are no features to suggest a specific or more serious condition [2].

Sagittal alignment, misunderstood as sagittal balance, describes the ideal alignment in the sagittal plane, resulting from the interplay between various organic factors. Any pathology that changes this equilibrium instigates sagittal malalignment and its compensatory mechanisms. As a result, sagittal malalignment is not limited to adult spinal deformity; its pervasiveness extends through most spinal disorders [3].

Sagittal balance alignment is the anteroposterior position of cranial spinal elements with respect to caudal elements. Sagittal balance is an impotant concept in spinal reconstruction [4] and cervical sagittal imbalance has been linked to poor health- 
related quality of life scores due to disabling symptoms of neck pain and neurological deficit and causes morphological changes in the spinal cord that lead to microvasculopathy, neuronal degeneration, and impairment of function [5]. So, recently the role of sagittal balance in cervical spine disorders and on the possible role of imbalance in predicting clinical and functional outcomes has become a focus of attention.

A forward position of the head relative to shoulder (Forward Head Posture [FHP]) is a measure of cervical sagittal [6]. So global spinal imbalance in the sagittal plane leads to development of clinical symptoms (non specific neck pain) and degenerative disease, which require additional perioperative care of treated patients [7].

We measured cervical sagittal balance by by c2-c7sagittal vertical axis as it is more accurate than measuring the angular orientation of the occiput relative to the thoracic inlet. In this study we give attention to how cervical balance affects outcome measures of multimodal treatment in NS Np patients [8].

So we hypothesis that patients with cervical sagittal balance have better outcome measures than patients with cervical sagittal imbalance in case of non specific neck pain.

A lot of studies use sagittal balance as prediction for surgical treatment like Radcliff who explained the importance of cervical balance in spinal reconstruction.

Also no one in physical therapy field use it in multimodal treatment so the aim of the study is to investigate the influence of cervical balance as predictor for the outcome measures of multimodal treatment program in patient with non specific neck pain.

\section{Material and Methods}

\section{A- Subjects:}

The cases diagnosed by neurosurgeon and referred to me at Damanhur Medical National Institute and. The subjects signed the institutionally approved consent form preceded the data collection for participation on study. Measurements were conducted prior to and after the course of treatment. Treatment was done 3 times/week for 10-12 weeks (began this treatment at 5 May 2018 and finished at 5 August 2018), 40 patients with non specific neck pain will be randomly assigned into 2 groups. And both group receive multimodal treatment.
Group A: Non specific neck pain patient with cervical sagittal imbalance while Group B: Non specific neck pain patient with cervical sagittal balance.

Patient to be admitted to the study should have the following inclusive criteria: Their age ranged from 25-40 years old, history of non specific neck pain for greater than 3 month, impairement of function and physical disability.

The exclusion criteria were as follow: Pregnant women. Nerve root entrapment, spinal cord compression, malignancy, acute infection and refusal to cooperate, diseases preventing physical loading, presence of vertbro basilar insufficiency, history of cervicalsurgery, patient with psychological disturbances, severe osteoporosis and fresh fractures and postural deformities (kyphosis-scoliosis).

\section{I- Instrumentation and scales for assessment:}

Patients were assessed before, after the treatment program. The assessment procedures included the following items:

1-Functional disability index: Functional disability of each patient was assessed by Arabic Neck Disability Index (NDI). It is valid and reliable tool [9]. It is consists of 10 multiple choice questions for neck pain, where the patient selects one sentence out of six that best describes their function, higher score 5 indicate great loss of function and lower score 0 indicate no disability.

The questions are measured on a 6-point scale from 0 (no disability) to 5 (full disability). The numeric response for each item was summed for score varying from 0 to 50 [10]. And percentage of disability scores was calculated. Scores of 10-28\% was considered mild disability, $30-48 \%$ was moderate, $50-68 \%$ was sever and $72 \%$ or more was complete disability [11]

2- Visual analogue scale: VAS consisted of a line, usually $10 \mathrm{~cm}$ long, the patient was instructed to place a vertical mark on to determine his pain, ranging from no pain or discomfort (0), to the worst pain [10] that the patient could feel [12].

3- Cervical active range of motion: The CROM (deluxe version-Performance Attainment Associates, Roseville, MN, USA, 2016; http://www. spineproducts.com) measures the cervical range of motion for flexion, extension, lateral flexion, and rotation using separate inclinometers. These inclinometers are attached to a frame similar to that for eyeglasses: One in the sagittal plane for flexion-extension. A second in the frontal plane 
for lateral flexion and a third in the horizontal plane for rotation. Two of these inclinometers have a gravity-dependent needle (in the sagittal and frontal planes) and the other has a magnetic needle (in the horizontal plane). A magnetic neck brace was worn by the patient. Measurements were expressed in degrees with high degree of validity and reliability [13].

Studies have declared it superior to the universal goniometer and visual estimation and superior to a single inclinometer [13]

4- $X$-ray: Mainly using anterior posterior view and lateral view to determine the sagittal alignment of the cervical (model: Dura diagnost which is digital radiographs system and manufactured by Philips company).

Sagittal Vertical Axis (cSVA.) was defined as the horizontal distance from the $\mathrm{C} 2$ plumb line to the $\mathrm{C} 7$ plumb line. The $\mathrm{C} 2$ sagittal plumb line is drawn with a lateral gravity plumb line from the center of $\mathrm{C} 2$; the center of $\mathrm{C} 2$ was noted by the intersection of crossing diagonals of the vertebral body of $\mathrm{C} 2$ on the lateral radiograph.

The C7 sagittal plumb line is drawn with a lateral gravity plumb line from the center of $\mathrm{C} 7$; the center was noted similar to $\mathrm{C} 2$. The distance between the plumb lines was measured as the shortest perpendicular distance between the 2 lines [14] .

\section{2- Evaluation procedure:}

- Pain intensity assessment: The patient was being in a relaxed position then gave him the appendix which contains VAS. The patients instructed to place a vertical mark on to indicate his pain, ranging from no pain or discomfort (0), to the worst pain that could possibly feel.

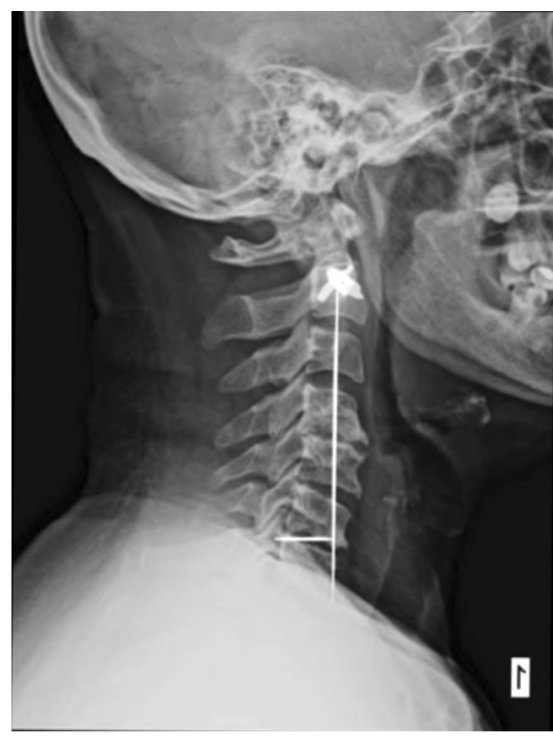

Fig. (1): Sagittal vertical axis C2-C7.

- Neck function assessment: We assessed the function of neck by Arabic NDI. Each question in questionnaire was explained in detail and the patients were asked to select one sentence out of six that best describes their neck function.

Cervical range of motion assessment: Each patient was instructed to sit in upright position and both hands rested on thigh. Hip and knee in flexion $90^{\circ}, \mathrm{CROM}$ was positioned on bridge of patient's nose and on ears as one would put on a pair of eyeglasses and strapped around head by Velcro straps, then measure range of motion for cervical region (flexion, extension, left side bending, right side bending, left rotation and right rotation).

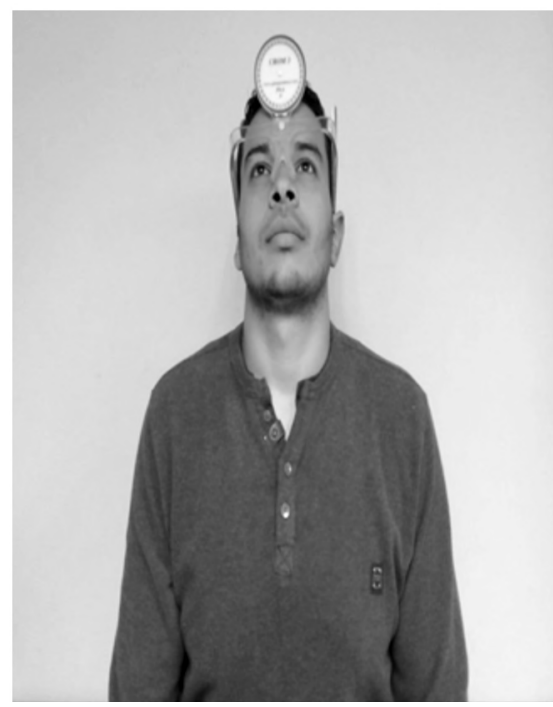

Fig. (2): Neck extension.

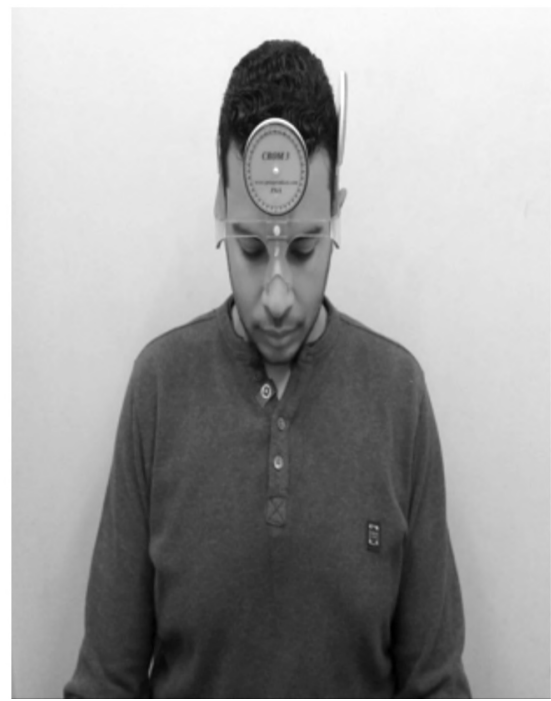

Fig. (3): Neck flexion. 


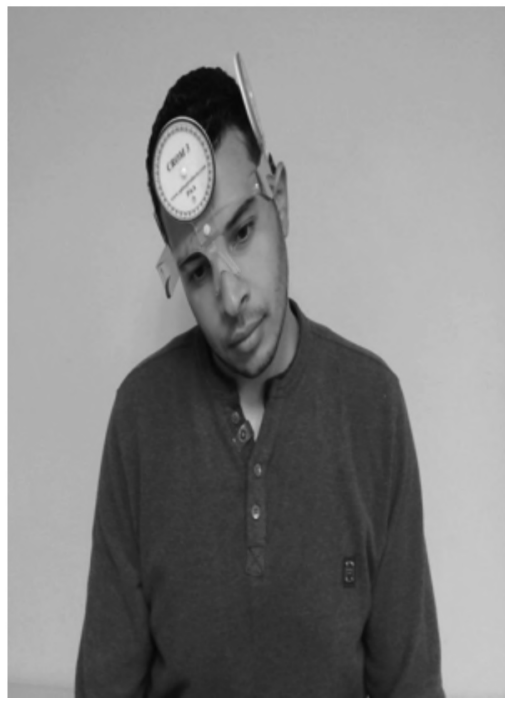

Fig. (4): Neck side bending.

\section{II- Treatment procedures:}

Stabilization exercises for the cervical region:

Stabilization exercises begin in supine position and progress to sitting, sitting on a large gym ball, standing with the back supported against a wall, and finally standing without support next step in cervical stabilization is progression to standing on an unstable surface.

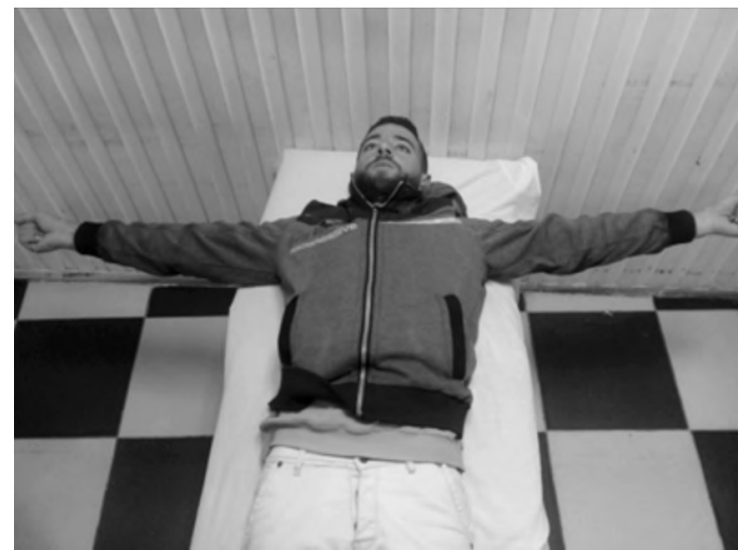

Fig. (6): Shoulder flexion 90 from supine position.

\section{Relaxation training:}

Relaxation training involves a reduction in muscle tension in the entire body or the region that is painful or restricted by conscious effort and thought. Training occcurs in a quiet environment with low lighting and soothing music or an auditory cue on which the patient may focus. The patient performs deep breathing exercises or visualizes a peaceful scene. When giving instructions the therapist uses a soft tone of voice [15].

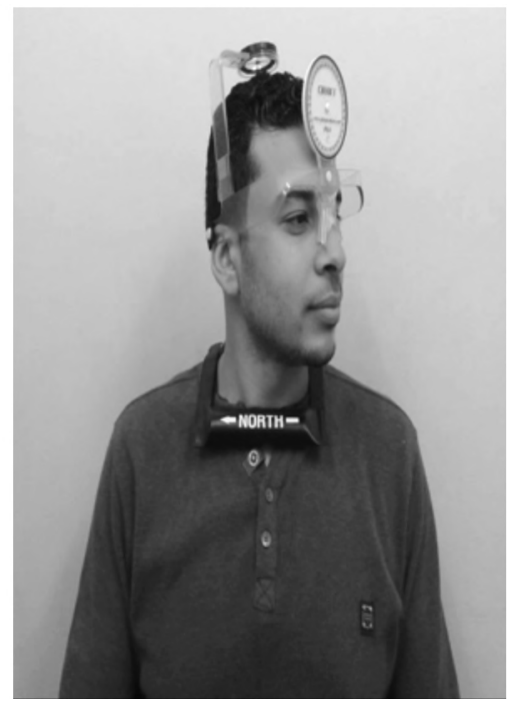

Fig. (5): Neck rotation.

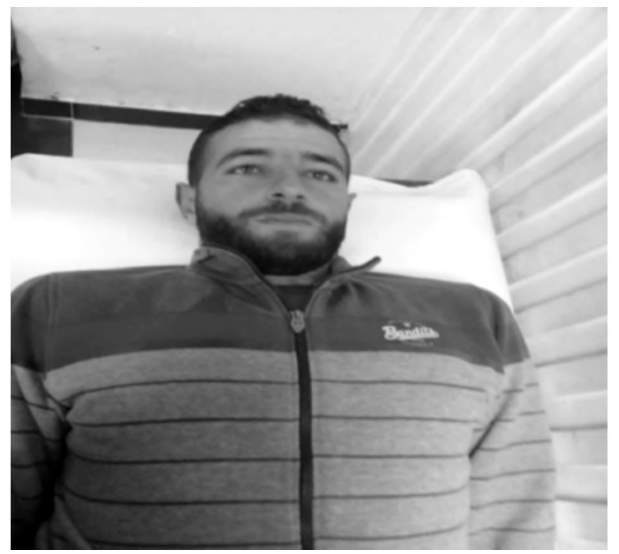

Fig. (7): Supine neutral head position.

\section{Eye fixation exercises (Gaze stability):}

A major benefit of some of these exercises is that they can be performed even when the patient has restrictions in neck movement due to pain or articular dysfunction, particularly the smooth pursuit movements. The exercises can be performed until some dizziness is provoked but not neck pain should be reproduced [16].

The first goal is to train eye-following movements. Generally these exercise begin in sitting but if needed, the patient can be positioned in lying for more support.

These photos show lateral eye movements but remember that you want to train all directions of movement i.e up/down, left/right, circular and diagonal movements. In terms of dosage you can commence at 5-10 second bursts and build to 30 seconds, performed as frequently as 5 times a day [17]. 


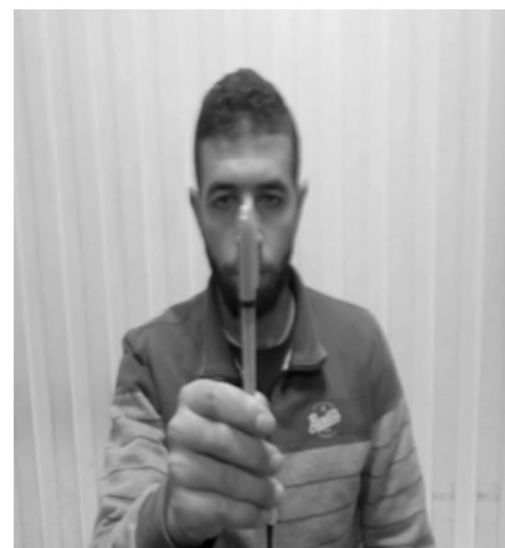

Fig. (8): Eye fixation from sitting position.

\section{Balance training:}

Childs et al., mentions that people with neck pain, postural balance,coordination of head movements and intersegmental coordination of the vertebrae of the cervical spine were impaired [17].

They do balance exercises (single leg stance, tandem stance, and standing on a wobble board), balance training is very effective to counteract impaired joint position sense and neck pain of the cervical spine [18]

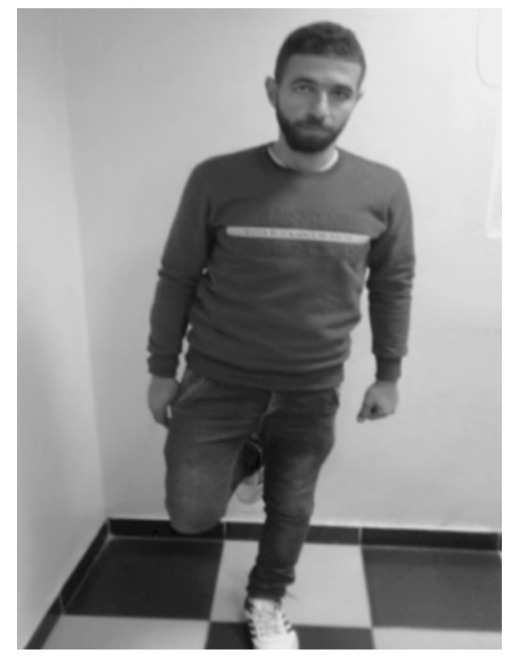

Fig. (9): Single leg stance.

\section{Results}

\section{General characteristics of the subjects:}

Comparing the general characteristics of the subjects of both groups revealed that there was no significance difference between both groups in the mean age, weight, height, or BMI ( $p>0.05)$.

Comparison of cervical Sagittal Vertical Axis (SVA) between group $A$ and $B$.

The mean \pm SD SVA of group A was $0.77 \pm 0.11$ $\mathrm{cm}$ while in group B was $1.24 \pm 0.14 \mathrm{~cm}$. The mean difference between both groups was $-0.47 \mathrm{~cm}$.
There was a significant decrease in the SVA of group A compared with that of group B $(p=0.0001)$.

Table (1): Descriptive statistics and $t$-test for comparing the mean age, weight, height and BMI of group A and B.

\begin{tabular}{|c|c|c|c|c|c|c|}
\hline & $\begin{array}{l}\text { Group A } \\
X \pm S D\end{array}$ & $\begin{array}{l}\text { Group B } \\
X \pm S D\end{array}$ & MD & $\begin{array}{c}t- \\
\text { value }\end{array}$ & $\begin{array}{c}p- \\
\text { value }\end{array}$ & Sign. \\
\hline Age (years) & $33.8 \pm 5.8$ & $31.6 \pm 4.88$ & 2.2 & 1.29 & 0.2 & NS \\
\hline Weight (kg) & $81.35 \pm 10.86$ & $78.35 \pm 8.34$ & 3 & 0.97 & 0.33 & NS \\
\hline Height $(\mathrm{cm})$ & $174.65 \pm 7.97$ & $174 \pm 9.69$ & 0.65 & 0.23 & 0.81 & NS \\
\hline BMI $\left(\mathrm{kg} / \mathrm{m}^{2}\right)$ & $26.66 \pm 3.17$ & $25.93 \pm 2.67$ & 0.73 & 0.79 & 0.43 & NS \\
\hline $\begin{array}{l}\bar{x}: \text { Mean. } \\
\text { SD }: \text { Standarc } \\
\text { MD }: \text { Mean Di }\end{array}$ & $\begin{array}{l}\text { Deviation. } \\
\text { fference. }\end{array}$ & $\begin{array}{l}p-\mathrm{v} \\
\mathrm{NS}\end{array}$ & ue & $\begin{array}{l}\text { Proba } \\
\text { Non S }\end{array}$ & $\begin{array}{l}\text { ity v } \\
\text { nific }\end{array}$ & \\
\hline
\end{tabular}

Table (2): $t$-test for comparison of mean value of SVA between group A and B.

\begin{tabular}{|c|c|c|c|c|c|c|}
\hline & $\begin{array}{l}\text { Group A } \\
X \pm S D\end{array}$ & $\begin{array}{l}\text { Group B } \\
X \pm \text { SD }\end{array}$ & MD & $\begin{array}{c}t- \\
\text { value }\end{array}$ & $\begin{array}{c}p- \\
\text { value }\end{array}$ & Sign. \\
\hline SVA $(\mathrm{cm})$ & \multicolumn{2}{|c|}{$0.77 \pm 0.111 .24 \pm 0.14$} & -0.47 & -11.3 & 0.0001 & $S$ \\
\hline $\begin{array}{ll}\bar{x} & : \text { Mear } \\
\text { SD } & : \text { Stan } \\
\text { MD } & \text { : Mear }\end{array}$ & $\begin{array}{l}\text { lard Deviatio } \\
\text { Difference. }\end{array}$ & & $\begin{array}{l}t \text {-va } \\
p \text {-va } \\
\mathrm{S}\end{array}$ & $\begin{array}{l}\text { e : Unp } \\
\text { e : Prob } \\
\text { : Sign }\end{array}$ & $\begin{array}{l}\text { aired } t \text {-va } \\
\text { ability } v \\
\text { ificant. }\end{array}$ & $\begin{array}{l}\text { lue. } \\
\text { lue. }\end{array}$ \\
\hline
\end{tabular}

Effect of cervical balance and time on cervical $R O M, N D I, V A S$ :

Within-group analysis there was a significant difference of, NDI and ROM (flexion, extension, $\mathrm{RT}$ rotation and LT rotation) pre-treatment at groups A, B ( $p=0.0001)$. There was no significant difference of VAS, LT bending and RT bending pretreatment ( $p$-value $>0.05)$. Between group analyses there was significant difference of NDI and ROM (flexion, extension, RT bending, LT bending, RT rotation and LT rotation) in two groups posttreatment as $p$-value $<0.05$ except VAS.

SVA (Sagittal Vertical Axis) contribute to interpretation of changes in ROM NDI except VAS. $R O M$ :

Effect of cervical balance and time on cervical

Multiple pairwise comparison showed that there was a significant increase in the cervical flexion, extension, right rotation and left rotation ROM of group B compared with that of group A pretreatment but no significance in right side bending and left side bending.

Also, there was a significant increase in the mean values of the cervical flexion, extension, right side bending, left side bending, right rotation and left rotation ROM of the group B post-treatment compared with that of group. 
Table (3): Mean cervical flexion ROM pre and post-treatment of group A and B.

\begin{tabular}{|c|c|c|c|c|c|c|}
\hline $\begin{array}{l}\text { Flexion } \\
\text { ROM } \\
\text { (degrees) }\end{array}$ & $\begin{array}{l}- \text { Pre } \\
X \pm S D\end{array}$ & $\begin{array}{l}- \text { Post } \\
X \pm S D\end{array}$ & MD & $\begin{array}{c}\% \text { of } \\
\text { change }\end{array}$ & $\begin{array}{c}p- \\
\text { value }\end{array}$ & Sig. \\
\hline Group A & $27.8 \pm 10.62$ & $35.9 \pm 11.46$ & -8.1 & 29.13 & 0.0001 & S \\
\hline Group B & $41.3 \pm 10.02$ & $50.85 \pm 11.64$ & -9.55 & 23.12 & 0.0001 & S \\
\hline MD & -13.5 & -14.95 & & & & \\
\hline$p$-value & 0.0001 & 0.0001 & & & & \\
\hline Sig. & $\mathrm{S}$ & $\mathrm{S}$ & & & & \\
\hline $\begin{array}{ll}\bar{x} & : \text { Mea } \\
\text { SD } & : \text { Stan } \\
\text { MD } & : \text { Mea }\end{array}$ & $\begin{array}{l}\text { ard Deviatio } \\
\text { Difference. }\end{array}$ & & $\begin{array}{l}p- \\
\mathrm{S}\end{array}$ & $\begin{array}{l}\text { : Proba } \\
\text { : Signif }\end{array}$ & $\begin{array}{l}\text { ility } \\
\text { cant. }\end{array}$ & \\
\hline
\end{tabular}

Table (4): Mean cervical extension ROM pre and posttreatment of group A and B.

\begin{tabular}{|c|c|c|c|c|c|c|}
\hline $\begin{array}{l}\text { Extension } \\
\text { ROM } \\
\text { (degrees) }\end{array}$ & $\begin{array}{l}- \text { Pre } \\
\mathrm{X} \pm \mathrm{SD}\end{array}$ & $\begin{array}{c}\text { Post } \\
\mathrm{X} \pm \mathrm{SD}\end{array}$ & MD & $\begin{array}{c}\% \text { of } \\
\text { change }\end{array}$ & $\begin{array}{c}p- \\
\text { value }\end{array}$ & Sig. \\
\hline Group A & $27.65 \pm 9.28$ & $36 \pm 8.07$ & -8.35 & 30.19 & 0.0001 & $S$ \\
\hline Group B & $37.25 \pm 6.84$ & $51.9 \pm 8.79$ & -14.65 & 39.32 & 0.0001 & S \\
\hline MD & -9.6 & -15.9 & & & & \\
\hline$p$-value & 0.001 & 0.0001 & & & & \\
\hline Sig. & $\mathrm{S}$ & $\mathrm{S}$ & & & & \\
\hline $\begin{array}{ll}\bar{x} & : \text { Mea } \\
\text { SD } & : \text { Stan } \\
\text { MD } & : \text { Mea }\end{array}$ & $\begin{array}{l}\text { rd Deviation } \\
\text { Difference. }\end{array}$ & & $\begin{array}{l}p- \\
\mathrm{S}\end{array}$ & $\begin{array}{l}\text { : Probal } \\
\text { : Signifi }\end{array}$ & $\begin{array}{l}\text { ility va } \\
\text { cant. }\end{array}$ & \\
\hline
\end{tabular}

Table (5): Mean cervical right bending ROM pre and posttreatment of group A and B.

\begin{tabular}{|c|c|c|c|c|c|c|}
\hline $\begin{array}{l}\text { Right bending } \\
\text { ROM } \\
\text { (degrees) }\end{array}$ & $\begin{array}{l}- \text { Pre } \\
X \pm S D\end{array}$ & $\begin{array}{c}\text { Post } \\
\bar{X} \pm \text { SD }\end{array}$ & MD & $\begin{array}{c}\% \text { of } \\
\text { change }\end{array}$ & $\begin{array}{c}p- \\
\text { value }\end{array}$ & Sig. \\
\hline Group A & $25.55 \pm 9.55$ & $31.65 \pm 9.61$ & -6.1 & 23.87 & 0.001 & S \\
\hline Group B & $29.45 \pm 9.86$ & $40.35 \pm 8.76$ & -10.9 & 37.01 & 0.0001 & S \\
\hline MD & -3.9 & -8.7 & & & & \\
\hline$p$-value & 0.21 & 0.005 & & & & \\
\hline Sig. & NS & $S$ & & & & \\
\hline $\begin{array}{ll} & : \text { Mean. } \\
\text { SD } & : \text { Standard } \\
\text { MD } & : \text { Mean Dif }\end{array}$ & $\begin{array}{l}\text { Deviation. } \\
\text { fference. }\end{array}$ & $\begin{array}{l}\mathrm{S} \\
\mathrm{N}\end{array}$ & JS & $\begin{array}{l}\text { Probabi } \\
\text { Signific } \\
\text { Non Sig }\end{array}$ & $\begin{array}{l}\text { lity valu } \\
\text { gant. } \\
\text { gnificant }\end{array}$ & \\
\hline
\end{tabular}

Table (6): Mean cervical left bending ROM pre and posttreatment of group A and B.

\begin{tabular}{|c|c|c|c|c|c|c|}
\hline $\begin{array}{l}\text { Left bending } \\
\text { ROM } \\
\text { (degrees) }\end{array}$ & $\begin{array}{l}- \text { Pre } \\
X \pm S D\end{array}$ & $\begin{array}{l}- \text { Post } \\
\mathrm{X} \pm \mathrm{SD}\end{array}$ & MD & $\begin{array}{c}\% \text { of } \\
\text { change }\end{array}$ & $\begin{array}{c}p- \\
\text { value }\end{array}$ & Sig \\
\hline Group A & $26.6 \pm 8.96$ & $33.1 \pm 9.06$ & -6.5 & 24.43 & 0.0001 & S \\
\hline Group B & $31.45 \pm 8.16$ & $44.55 \pm 7.62$ & -13.1 & 41.65 & 0.0001 & S \\
\hline MD & -4.85 & -11.45 & & & & \\
\hline$p$-value & 0.08 & 0.0001 & & & & \\
\hline Sig. & NS & $\mathrm{S}$ & & & & \\
\hline $\begin{array}{ll}\bar{x} & : \text { Mean. } \\
\text { SD } & : \text { Standar } \\
\text { MD } & : \text { Mean D }\end{array}$ & $\begin{array}{l}\text { d Deviation. } \\
\text { ifference. }\end{array}$ & & $\begin{array}{l}p \text {-valu } \\
\mathrm{S} \\
\mathrm{NS}\end{array}$ & $\begin{array}{l}\text { : Probab } \\
\text { : Signific } \\
\text { Non } \mathrm{Si}\end{array}$ & $\begin{array}{l}\text { ility valu } \\
\text { sant. } \\
\text { gnificant }\end{array}$ & \\
\hline
\end{tabular}

Table (7): Mean cervical right rotation ROM pre and posttreatment of group A and $\mathrm{B}$.

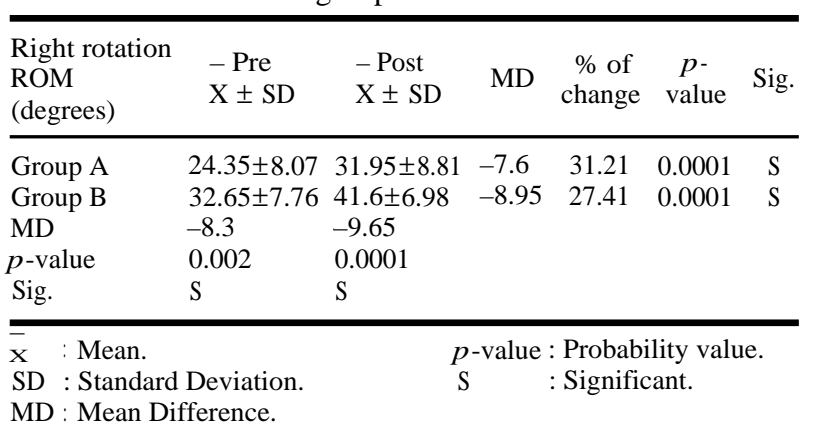

Table (8): Mean cervical left rotation ROM pre and posttreatment of group A and B.

\begin{tabular}{|c|c|c|c|c|c|c|}
\hline $\begin{array}{l}\text { Left rotation } \\
\text { ROM } \\
\text { (degrees) }\end{array}$ & $\begin{array}{l}- \text { Pre } \\
X \pm S D\end{array}$ & $\begin{array}{c}\text { Post } \\
\mathrm{X} \pm \mathrm{SD}\end{array}$ & MD & $\begin{array}{c}\% \text { of } \\
\text { change }\end{array}$ & $\begin{array}{c}p- \\
\text { value }\end{array}$ & Sig. \\
\hline Group A & $27.85 \pm 8.44$ & $35.6 \pm 8.4$ & -7.75 & 27.82 & 0.0001 & S \\
\hline Group B & $34.85 \pm 6.43$ & $43.9 \pm 9.36$ & -9.05 & 25.96 & 0.0001 & S \\
\hline MD & -7 & -8.3 & & & & \\
\hline$p$-value & 0.005 & 0.005 & & & & \\
\hline Sig. & $S$ & $\mathrm{~S}$ & & & & \\
\hline $\begin{array}{ll}\bar{x} & \text { Mean. } \\
\text { SD } & : \text { Standar } \\
\text { MD } & : \text { Mean D }\end{array}$ & $\begin{array}{l}\text { Deviation. } \\
\text { fference. }\end{array}$ & & & $\begin{array}{l}\text { : Probab } \\
\text { : Signifi }\end{array}$ & $\begin{array}{l}\text { ility v } \\
\text { cant. }\end{array}$ & \\
\hline
\end{tabular}

Table (9): Mean cervical flexion ROM pre and post-treatment of group A and B.

\begin{tabular}{|c|c|c|c|c|c|c|}
\hline $\begin{array}{l}\text { Flexion } \\
\text { ROM } \\
\text { (degrees) }\end{array}$ & $\begin{array}{l}- \text { Pre } \\
\mathrm{X} \pm \mathrm{SD}\end{array}$ & $\begin{array}{l}\text { - Post } \\
\mathrm{X} \pm \mathrm{SD}\end{array}$ & MD & $\begin{array}{c}\% \text { of } \\
\text { change }\end{array}$ & $\begin{array}{c}p- \\
\text { value }\end{array}$ & Sig \\
\hline Group A & $27.8 \pm 10.62$ & $35.9 \pm 11.46$ & -8.1 & 29.13 & 0.0001 & S \\
\hline Group B & $41.3 \pm 10.02$ & $50.85 \pm 11.64$ & -9.55 & 23.12 & 0.0001 & $S$ \\
\hline $\mathrm{MD}$ & -13.5 & -14.95 & & & & \\
\hline$p$-value & 0.0001 & 0.0001 & & & & \\
\hline Sig. & $S$ & $\mathrm{~S}$ & & & & \\
\hline $\begin{array}{ll}\bar{x} & : \text { Mea } \\
\text { SD } & : \text { Stan } \\
\text { MD } & : \text { Mea }\end{array}$ & $\begin{array}{l}\text { dard Deviatio } \\
\text { n Difference. }\end{array}$ & & \multicolumn{4}{|c|}{$\begin{array}{l}p \text {-value : Probability value. } \\
\mathrm{S} \quad \text { : Significant. }\end{array}$} \\
\hline
\end{tabular}

Comparison between mean VAS pre and posttreatment of group $A$ and B:

Multiple pairwise comparison showed that there was no significant difference in the mean values of VAS pre-treatment between group A and $\mathrm{B}(p=$ 0.34 ). Also, there was no significant difference in VAS between group A and B post-treatment ( $p=$ 0.07).

Comparison between mean NDI pre and posttreatment of group $A$ and $B$ :

Multiple pairwise comparison showed that there was a significant decrease in the mean values of NDI of the group B pre-treatment compared with that of group A $(p=0.003)$. Also, there was a significant decrease in the NDI of the group B posttreatment compared with that of group $\mathrm{A}(p=$ 0.0001). 
Table (10): Mean VAS pre and post-treatment of group A and B.

\begin{tabular}{|c|c|c|c|c|c|c|}
\hline VAS & $\begin{array}{l}- \text { Pre } \\
\mathrm{X} \pm \mathrm{SD}\end{array}$ & $\begin{array}{c}\text { Post } \\
\bar{X} \pm S D\end{array}$ & MD & $\begin{array}{c}\% \text { of } \\
\text { change }\end{array}$ & $\begin{array}{c}p- \\
\text { value }\end{array}$ & Sig \\
\hline Group A & $7.52 \pm 0.92$ & $3.62 \pm 1.17$ & 3.9 & 51.86 & 0.0001 & S \\
\hline Group B & $7.22 \pm 1.04$ & $2.92 \pm 1.23$ & 4.3 & 59.55 & 0.0001 & S \\
\hline $\mathrm{MD}$ & 0.3 & 0.7 & & & & \\
\hline$p$-value & 0.34 & 0.07 & & & & \\
\hline Sig. & NS & NS & & & & \\
\hline \multirow{3}{*}{\multicolumn{3}{|c|}{$\begin{array}{ll}\overline{\mathrm{x}} & : \text { Mean. } \\
\mathrm{SD} & : \text { Standard Deviation. } \\
\mathrm{MD} & : \text { Mean Difference. }\end{array}$}} & \multicolumn{4}{|c|}{$p$-value : Probability value. } \\
\hline & & & $S$ & : Sign & ficant. & \\
\hline & & & NS & : Non & ignifica & \\
\hline
\end{tabular}

Table (11): Mean NDI pre and post-treatment of group A and B.

\begin{tabular}{|c|c|c|c|c|c|c|}
\hline NDI & $\begin{array}{l}- \text { Pre } \\
X \pm \mathbf{S D}\end{array}$ & $\begin{array}{c}\text { Post } \\
\mathbf{X} \pm \text { SD }\end{array}$ & MD & $\begin{array}{c}\% \text { of } \\
\text { change }\end{array}$ & $\begin{array}{c}p- \\
\text { value }\end{array}$ & Sig. \\
\hline Group A & $21.9 \pm 4.47$ & $16.4 \pm 4.33$ & 5.5 & 25.11 & 0.0001 & S \\
\hline Group B & $17.4 \pm 4.42$ & $10.1 \pm 4.05$ & 7.3 & 41.95 & 0.0001 & $S$ \\
\hline MD & 4.5 & 6.3 & & & & \\
\hline$p$-value & 0.003 & 0.0001 & & & & \\
\hline Sig. & $\mathrm{S}$ & $\mathrm{S}$ & & & & \\
\hline $\begin{array}{ll}\bar{x} & \text { Mea } \\
\text { SD } & : \text { Star } \\
\text { MD } & \text { Mea }\end{array}$ & ard D & & \multicolumn{4}{|c|}{$\begin{array}{l}p \text {-value : Probability value. } \\
\mathrm{S} \quad \text { : Significant. }\end{array}$} \\
\hline
\end{tabular}

The effect of sagittal vertical axis on pain, neck disability and range of motion after multimodal treatment:

Sagittal vertical axis contribute in changes in ROM and NDI post-treatment except VAS.

The following are the results of the effect of SVA on ROM.

CSVA contribute to interpretation of change of about $22 \%$ flexion, $37.5 \%$ extension, $20 \%$ right side bending, $26.4 \%$ left side bending, $16 \%$ right rotation, $13 \%$ left rotation and $24.4 \%$ of NDI except VAS.

\section{Discussion}

The result of this study demonstrate that the patient with cervical balance have better outcomes than cervical imbalance in case of non specific neck pain except VAS and smaller value of CSVA indicate worsening of clinical outcomes.

CSVA contribute to interpretation of change of about $22 \%$ flexion, $37.5 \%$ extension, $20 \%$ right side bending, $26.4 \%$ left side bending, $16 \%$ right rotation, $13 \%$ left rotation and $24.4 \%$ except VAS. Also illustrate increase in the cervical flexion, extension, right side bending, left side bending, right rotation and left rotation $\mathrm{ROM}$ of the group B post-treatment compared with that of group A, so sagittal balance affect mainly the outcomes of multimodal treatment in non specific neck pain patients.
Many studies support the importance of sagittal balance in reconstructive surgery of the spine and in healthy individuals [19-24]. Also measuring the radiographic spinopelvic parameters of sagittal balance to prevent functional disability is a routine part of many interventions for degenerative spinal diseases. Sagittal balance must be carefully considered before any surgery, limited or not, and especially at the lumbar level and, above all, if the L4-L5-S 1 levels the lordosis) are included in the fusion [25]. So surgical planning in sagittal imbalance is recognized as a key step of treatment to ensure good clinical results [26]

Also kris radkliff supported this study and mention that cervical spine sagittal balance,was found to be related to outcome of cervical laminectomy and fusion [4]. Other authors contradict this study and have found no relationship between radiographic parameters and clinical outcome in cervical laminectomy and fusion [27]

Many studies concentrate in assessing the prognostic factors as they help therapists to identify patients with a good prognosis or patients at risk. For those at risk, this would allow the treatment approach to be redirected to address their specific needs [28].

There are different factors predicting response to a multimodal treatment program. A high Neck Disability Index (NDI) score, a high Numeric Rating Scale (NRS) score for pain in the upper extremities, a low Numeric Rating Scale (NRS) score for neck-pain, and a trauma in the patient's history decrease the odds of having a positive outcome after the given treatment program.

A higher age, presence of headache, low back pain, and having low levels of depression increase the odds to complete the multimodal treatment program. It is important to recognize and assess these factors clinically to be able to predict the outcome after the given treatment program. For those at risk, this would allow the treatment approach to be redirected to their specific needs for completing the treatment [28].

It is the first study that demonstrates the relation between sagittal balance and outcome measures in cervical region mainly in physical therapy field.

Limitation of this study are small number of patient, long time of multimodal treatment program and no concentration in relation between whole spine curvtures. 
We recommend further studies on regaining cervical balance and concentrate on further studies to be conducted to investigate the relation ship between age and cervical sagittal vertical axis and how age affect this angle and cervical balance.

\section{Conclusion:}

Cervical sagittal balance is effective in predicting multimodal treatment outcome measures (ROM and neck function) in Nonspecific Neck Pain (NSNP). Patients with cervical sagittal balance have better outcome measures (improving ROM, decrease pain intensity and improving neck function) than patients with cervical sagittal imbalance in case of non specific neck pain.

\section{References}

1- RENÉ FEJER, KIRSTEN OHM KYVIK, and JAN HARTVIGSEN: The prevalence of neck pain in the world population: A systematic critical review of the literature, 2006.

2- BINDER A.: "The diagnosis and treatment of nonspecific neck pain and whiplash." Eura Medicophys, 43 (1): 79 89, 2007.

3- DIEBO B.G., VARGHESE J., et al.: "Sagittal alignment of the spine, 2015".

4- KRIS E.RADCLIFF N., CHRISTOPHER K., et al.: "C1 plumb line and cervical sagittal balance predict the outcome of cervical laminectomy and fusion, 2015".

5- Le HUEC J.C., CHAROSKY, et al.:" Sagittal imbalance cascade for simple degenerative spine and consequences: Algorithm of decision for appropriate treatment", 2011.

6- AVANISH G. PATWARDHAN, ROBERT M., et al.: "Postural Compensation and Disc. Mechanics in Forward", 2013.

7- MINORI KATO, TAKASHI NAMIKAWA, et al.: " Effect of Cervical Sagittal Balance on Laminoplasty in Patients With Cervical Myelopathy, 2017.

8- PETER L. COHN, WILLIAM RYAN SPIKER, KRIS E. RADCLIFF and ALEXANDER R. VACCARO: Cervical sagittal balance: What is normal and what is the effect on reconstruction outcomes, 2016.

9- AFAF SHAHEEN, MOHAMMED TAHER and HOWARD VERNON: "Cross-Cultural Adaptation, Reliability and Validity of Arabic Version of Neck Disability Index in Patients with Neck Pain", 2013.

10- MACDERMID J.C., WALTON D.M., AVERY S., BLANCHARD A., ETRUW E., MCALPINE C. and GOLDSMITH C.H.: Measurement 124 properties of the neck disability index: A systematic review. Journal of orthopaedic \& sports physical therapy, 39 (5): 400-C12, 2009.

11- VERNON H. and MIOR S.: The Neck Disability Index: A study of reliability and validity. Journal of manipulative and physiological therapeutics, 14 (7): 409-15, 2009.
12- BOONSTRA A.M., SCHIPHORST PREUPER H.R., RENEMAN M.F., POSTHUMUS J.B. and STEWART R.E.: Reliability and validity of the visual analogue scale for disability in patients with chronic musculoskeletal pain, 2008.

13- TOUSIGNANT M., De BELLEFEUILLE L., O'DONOUGHUE S. and GRAHOVAC S.: Criterion validity of the cervical range of motion 128 (CROM) goniometer for cervical flexion and extension. Spine, 25 (3): 324-30, 2000.

14- MANOHARAN S.R., JOSHI D., OWEN M., THESIS S.M. and DEINLEIN D.: Relationship of cervical sagittal vertical alignment after sagittal balance correction in adult spinal deformity, 2018.

15- CAROLYN KISNER and LYNN ALLEN COLBY: Therapeutic exercises foundation and techniques. 6 th edition, 2012.

16- STERLING M., FALLA D., JULL G., TRELEAVEN J. and O'LEARY S.: Whiplash, headache, and neck pain: Research-based directions for physical therapies: Elsevier Health Sciences, 2008.

17- CHILDS J.D., CLELAND, et al.: Neck pain: Clinical Functioning, practice guidelines linked to the International Classification of Disability, and Health from the Orthopedic Section of the American Physical Therapy Association. Journal of Orthhopedic and Sports Physical Therapy, 38, A1-A34, 2008

18- KONSTANTIN BEINERT and WOLFGANG TAUBE: The Effect of Balance Training on Cervical Sensorimotor Function and Neck Pain. Journal of motor behavior, 45 (3): 271-68, 2013.

19- O'SHAUGHNESSY B.A. and ONDRA S.L.: Measuring, preserving, and restoring sagittal spinal balance. Neurosurg. Clin. N. Am., 18: 347-56, 2007.

20- VEDANTAM R., LENKE L.G., KEENEY J.A. and BRIDWELL K.H.: Comparison of standing sagittal spinal alignment in asymptomatic adolescents and adults. Spine (Phila Pa 1976); 23: 211-5, 1998.

21- VAZ G., ROUSSOULY P., BERTHONNAUD E. and DIMNET J.: Sagittal morphology and equilibrium of pelvis and spine. Eur. Spine J., 11: 80-7, 2002.

22- HAMMERBERG E.M. and WOOD K.B.: Sagittal profile of the elderly. J. Spinal Disord. Tech., 16: 44-50, 2003.

23- GELB D.E., LENKE L.G., BRIDWELL K.H., BLANKE K., McENERY K.W.: An analysis of sagittal spinal alignment in 100 asymptomatic middle and older aged volunteers. Spine (Phila Pa 1976); 20: 1351-8, 1995.

24- LAZENNEC J.Y., RAMARE S., ARAFATI N., et al.: Sagittal alignment in lumbosacral fusion: Relations between radiological parameters and pain. Eur. Spine J., 9: 47-55, 2000.

25- Le HUEC J.C., THOMPSON W., MOHSINALY Y. et al.: Eur. Spine J. Sagittal balance of the spine. European Spine Journal, 2019.

26- LANGELLA F., VILLAFAÑE J.H., DAMILANO M., et al.: Predictive Accuracy of Surgimap Surgical Planning 
for Sagittal Imbalance: A Cohort Study. Spine (Phila Pa 1976). 2017 Nov. 15, 42 (22): E1297-E1304, 2017.

27- HOUTEN J.K. and COOPER P.R.: Laminectomy and posterior cervical of theposterior longitudinal ligament: Effects on cervical alignment, spinal cord compression, and neurological outcome. Neurosurgery, 52 (5): 10817 [discussion 1087-8], 2003.

28- R. De PAUW, J. KREGEL, C. De BLAISER, et al.: Identifying prognostic factors predicting outcome in patients with chronic neck pain after multimodal treatment: A retrospective study, 2005.

\title{
تآثير التوانذ العنقى فى نتيجة البرثامج العلاجى العاجى

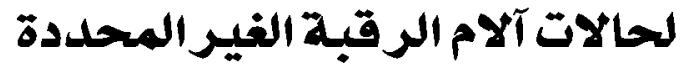

\author{
آجريت هذه الربسالة على آربعين مريضاً يعانون من آلام الرقبة الغير محددة وكان متوبسط العمر من الخامسة والعشرف إلى الآربعين سنة.

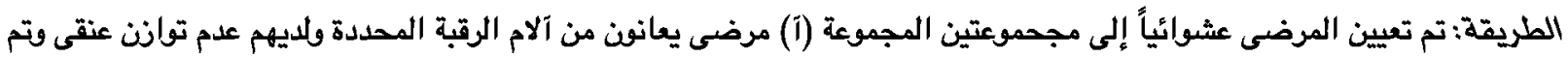 \\ تنفيذ البرنامج العلاجى عليهم المجموعة (ب) مرضى يعانون من آلام الرقبة المحددة ولديهم توانت عنقى وتم تنفيذ البرنامج العلاجى.

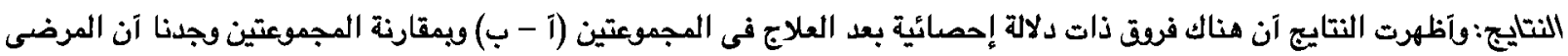

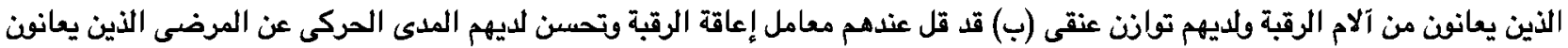

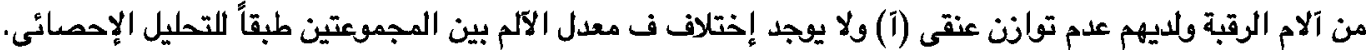

